LEGAL AND POLITICAL SCIENCE

\title{
INEQUALITY AND RIGHT-WING POPULISM
}

\author{
Lali Kapanadze, Academic Doctor of Social Sciences; Associate Professor legal and Political \\ Science; Tbilisi, Georgian Technical University \\ DOI: https://doi.org/10.31435/rsglobal_conf/25112020/7244
}

\begin{abstract}
According to Cambridge dictionary, in 2017 the most popular word was Populism. What is Populism? - Is it achievement of our era, or its roots comes from our remote past? According to scientific research, populism existed in ancient Roman period as an ideological political movement known as the Populist Party. It expressed the interests of ordinary people.

Today populism is a natural phenomenon of Democratic political regimes. Populist perception is a special democratic component of political culture, that is realized by the population who are involved in political movements. The amplitude of its usage is so diverse that it's difficult to find an exact scientific definition.

Today populism is a main political phenomenon and is mainly used during pre-election periods, political debates and with the purpose of convincing or manipulating consciousness of society. In addition, political leaders often use aggressive national-populist rhetoric.
\end{abstract}

Keywords: Populism, Inequality, right-wing populism, Populist Party, Democratic political regimes.

Introduction. Equality means the principle, according to which each citizen has equal values and political rights. As German politican, philosopher and scientist Hanna Arendt points out in a different eras equality was defined in a different ways: Isonomy - in Antique epoch meant equal protection of law. By their nature people were unequal, but as citizens they had equal legal liabilities.

In Enlightenment era people considered that all people were equal, but political and economical system and society put them in an unequal position. [1] Thomas Jeferson declared: "Equal rights to everyone, and no special privileges to anyone!". According to John Lock's view - People are free and have equal rights since the day of their birth.

In 1948 UN accepted the declaration of human rights protection, according to which all people are equal to each other in spite of their colors, race, national or ethnic origin, political or economic equality. Unfortunately, nowadays political and economic inequality has become more and more common. Poverty increases day by day. The world society is divided into four parts: 600 million people are poor, their daily income is 1.90 USD per day; 3.2 billion people have financial difficulties. Their daily income is from 1.90 to 11 USD; 3.6 billion people belong to middle class and 200 million people are rich, their daily income is more than 110 USD per day. These are data of 2018 [2]. According to new data in 2020, 3.8 million people live below the poverty level [3]

During its historical development, the world has gone through periods when there were different kinds of violations of human rights. There were periods when the wealth was transferring from one generation to its descendants (primeval era, slave-owning and Feudalism period) and Capitalism, when there was confrontation between bourgeoisie and proletariat. Because of inequality there were revolutions, eg: The slogan of 1789 French Revolution was "Equality, Freedom, Brotherhood". In the Constitution it says: "Authorities are established with the purpose to give people possibilities to use their indivisible rights: Equality, Freedom, Security, Sense of property."

In spite of Democratic regimes, inequality still remains a big challenge for society to this day. Equality in Democracy signifies equal rights and possibilities of development.

Main Text. Who are Populists?

According to Cambridge dictionary in 2017, the most popular word was Populism. This happened after the head of Rome Catholic Church warned the world about the danger of spreading dictatorship in Europe. At that time Europe was undergoing political and economical crisis. In his interview for the newspaper El-Pasi Franciscan, he first expressed his worries about increasing populism all around the world.

The best example of European Populism was Germany in 1933. The country was quite weak and needed a strong leader. That's the period when Adolf Hitler appeared. He was "elected by the 
people and he was the one who destroyed them" - noted Pope. To his mind economic and migration problems in Europe as well as growth of Populism really was a big challenge.

It's interesting what is Populism - Is it achievement of our epoch or does it comes from past centuries? As research shows, Populism existed in old Rome and it was known as Populist party that protected the rights of ordinary people - Clebsis.

Nowadays the world political experience shows that populism becomes active when the countries are undergoing big social-economical changes, during transitional periods and before elections. The amplitude of using this terminology is so diverse, that scientists find it difficult to make a concrete scientific definition. It may be: National, Agrarian, Economical, Political, also the style of political leader, Right wing or Left wing course, ex:

The major methods of Right wing Populism are:

Establishment of peace by using law enforcement; dictatorship; creating "economic miracles"; nationalism; fascism; demagogy; xenophobe; reactionary politic; controlling governmental organizations; manipulation of people's consciousness, and forced revolution.

The major methods of Left wing Populism are:

Establishing justice, ecological problems, freedom, equality, brotherhood, control of Governmental structures, establishing social order, economic liberalism, implementing social reforms, securing unemployment, arranging essential social problems, giving propriety to national problems, nonviolent revolution, and fighting against bureaucracy.

Elites and Populism. Famous Italian Scientist Umberto Eko in his book "Crabs Movement" has written that contemporary populism has nothing in common with people just because "people" don't exist and they become an object of interest only during elections. Populist doesn't rely on people, but relies on some certain projection of society that totally supports it. Populist always tries to avoid any kind of conflict with people.

Nowadays the issue of poverty and inequality has become more and more urgent in the world. Very often economic inequality is associated with unfairness that causes political instability. This circumstance, as we have already mentioned, becomes quite a good reason of spreading Populism. Financial and economic crisis become one of the main reason of developing populism in Europe and America, too. Political and business elites have more and more influence on ongoing political process that reveals in corruption, nepotism, improper exploitation of state property, lobbying private businesses or political leaders. Increase of crime also becomes an issue. Increase of inequality makes the life of poor people even worse. This fact enables populism to become widespread quickly. This is the period when new political faces begin to show up, and they manipulate people's problems and make big promises about improvement of their lives.

Political elite get quite a big benefit by using populist methods. Higher social polarization of society is a result of a more successful populist political movement. Polarization may appear in the confrontation of different classes, social groups, and political parties. Poverty and inequality may be defined as an incapacity to be included in valuable social activities. There exists a broader definition as well; according to United Nation's definition, poverty includes such elements as "deficiency of taking part in decision making process, endeavor of personal dignity, and lack of legal power".

It can be said that social polarization of society increases the role of populism in global politics. Political leaders use dissatisfaction of society and they suggest the electorate to arrange their problems quickly and easily.

Economic globalization was followed not only by general growth of the world economy, but aggravation of inequality, too. This process damaged low paid workers much because in this battle they were competing with non-qualified immigrants. Today political issues are arranged by the wealth elite.

Equality is a very important element of modern democracy. Without this it's impossible to develop economically and politically. Equality is a precondition of well being that gives people possibilities to be included in the economic development process, to develop self creativity, and have a voice in state government.

There are lots of discussions about the theories of justice and inequality. Ex: Theory of utilitarianism. This theory is the work of Bentams???? and John Mill. According to their view, the best rule is the rule that saves people's resources. However, how can we build society that will have equal rights, and political and social environment? How can we combat poverty, hunger, and increase income for ordinary people? 
And finally, if we look back in history, we will discover that since the beginning of recorded history, there has always been inequality and confrontation between different classes and it was quite difficult to eradicate it.

Conclusions. Social and economic inequality, low economic growth, and poverty are a constant subject of discussion. Inequality of income causes economic instability, and health and social issues as well. Populist leaders use this circumstance quite well. They give lots of promises to the electorate and easily come into power.

Educated society can easily combat populism, if they have skills to analyze political situations and are not so easily influenced by them. These kind of people are capable to analyze information and make decisions based on the conclusions.

\section{REFERENCES}

1. Arendt, H. (1990). On Revolution. London: Penguin Books

2. Retrieved from http://www.vestifinance.ru/articles/84123 Растущее неравенство подпитывает популизм

3. Retrieved from https://imedinews.ge/ge/theme/314/rogor-ganvaskhvaot-populistebi-traditsiulipolitikosebisgan-instruqtsia

4. Retrieved from http://european.ge/chantal-muffe-populisturi-momenti/

5. Bert N. Adams, R.A. Sydie, "Sociological Theory," Pine Forge Press Thousand Oaks, California, London, New Delhi, 2001, pp. 346-356.

6. Read more at: http://european.ge/utanascorobis-shemcireba-ganvitarebisa-da-ketildgeobis-fundamenturi-piroba/ Copyright (C) European.ge

7. "Populism and Mas media, Culture and Intellectuals. Retrieved from https://burusi.wordpress.com/2010/05/29/umberto-eco- 